\title{
The dynamics of audit market and financial reporting under International Financial Reporting Standards: the case of Romanian listed companies
}

\author{
Marta Tache ${ }^{\text {a, } 1}$ \\ ${ }^{a}$ Bucharest University of Economics Studies, Romania
}

\begin{abstract}
Research question: The purpose of this article is to analyze the dynamics of audit market related to the audit services and financial reporting in accordance with International Financial Reporting Standards. Motivation: Although there is a solid foundation of rules and principles, the practical controversy over the rule of law, the features of the financial market, the characteristics of the accounting regulation process and the ability to adapt the environment seem to be endless. A credibility benchmark is made by the auditor's opinion that increases the reliability of financial statements, thus providing investors with assurance about the entity's independence. In this context, a strong maturation of Romanian market seems to improve the institutional context under IFRS adoption and an increased number of companies audited by Big 4 reveals a solid audit market. Idea: The main purpose of the research is to investigate the actual circumstances regarding International Financial Reporting Standards and the changes on audit market regulated by International Standard on Auditing (IAS), regarding Romanian listed companies. The in-depth knowledge of these elements makes it possible to highlight the existing achievements, thus marking a bond between IFRS and IAS, as two congruent standards. Data: In the present survey, a sample of 20 companies listed on the Bucharest Stock Exchange, Premium Shares, during 2016-2018 has been analyzed. Tools: The study implies a quantitative model based on Whitney test for verifying the association between the type of auditor and the audit opinion in the context of IFRS. Findings: The result indicates that the majority of firms is audited by Big 4 and a change of audit firm is not directly associated to the change of audit opinion after the adoption of IFRS became mandatory. In the same time, the present survey shows a continuous improvement of the audit market under IFRS adoption.
\end{abstract}


Keywords: IFRS, audit market, reporting, Big 4, audit opinion

\section{JEL codes: M42}

\section{Introduction}

This article investigates how the audit market for listed companies evolved in recent years in an institutional context characterized traditionally by a low presence of Big 4 and a low relevance of the audit opinion. In 2010, the European Commission manifested multiple concerns about the European Union market in the Green Paper (policy options for progress towards a European contract law for consumers and business): "Such a concentration may involve a risk accumulation and a collapse for the whole system of firms that can lead to the destruction of the entire audit market." These concerns are rooted in a theoretical premise that highlights this excessive concentration, which corresponds to the effects of domination and the total lack of competition with implications for quality and audit costs. For a better understanding of this topical issue, McInnis and Mergenthaler (2012) and Wieczynsca (2013) have explained the Big 4 oligopoly through the complexity of global accounting standards that increases the entry barriers of Non-Big 4 firms to the global market. Then, the introduction of IFRS rules at EU level has changed the corporate accounting, generating an increase in complexity and uncertainty in the preparation of financial statements. Moreover, Pong (2003) examines the changes in the US market structure with regard to audit services targeting the gradual shift of companies from Big 8 to Big 6. The same increase in market share was also observed by other researchers in the field, Beattie and Fearnley (1994) at the Big 4 companies.

Auditing was defined as "politically neutral technique of verifying the accounts" (Klarskov, 1998), "guardians of trust", a static activity to control the image of a company (Richard, 2006) or watchdogs (Reckers et al., 2007). Globalization is characterized by big number of multinationals, the commerce between foreign countries and the adherence of human beings to global organizations (Nobes \& Parker, 2008). In the same vein, big auditing companies are correlated with the auditing internalization developed in Anglo-Saxon countries. Additionally, Big 4 evolution is associated with auditing and consulting services (Zeff, 2003a) and the objectives from ethical to commercial changed in time (Klarskov, 1998).

The first researches in the field have been made by DeAngelo (1981) and Fung et al. (2009) who debated the financial audit market and highlighted the impact of the Big 4 globally. They provide a high quality of evidence through: human, financial and software resources, experience, solid knowledge, quality control procedures, and their credibility. Therefore, in the financial audit market an oligopoly was created, which led to the impossibility of other companies to access important customers. At 
European Union level, the rotation of firms auditing was encouraged because most financial institutions are audited by Big 4 (Fung et al., 2009).

Regarding the audit market, the first researcher was Simunic (1980), who analyzed the size of audit spending in the United States, studying whether Big 4 companies at that time, they are closed or merged, they get to Big 4 record much higher audit costs than other companies. The research was continued by Francis and Simon (1987) who observed a supplement in the share of audit costs. In the period 1978-198 Pamrose (1985) and Simon (1987) reached the following results: 36 companies out of a total of 173 companies were not audited by Big 8 . The companies with a percentage of 79 points audited by Big 8 testify about the existing competition in the free audit market and the high level of spending on Big 4 audit services.

In the UK, Taffler and Ramalinggam (1982) analyze the period 1978-1980, and the results show that $38 \%$ of companies are not audited by Big 4 . In Germany, between 2005 and 2007, Hoelbacher (2009), Koehler et al. (2010) and Sattler (2011) analyze the 2005-2007 period, and Big 4 accounts for $93 \%$ of the total volume of firms. In Australia, Hay and Jeter (2008) and Ferguspm et al. (2014) marks a 90\% mark for Big 4 audited firms in 2007. In Mexico, the Toscano and Garcia-Benau (2014) authors for the 2000-2007 period account for 97\% for the four companies in Big 4 . However, analyzing the audit reports, there was an increase in the market share of Big 4 companies from $40.51 \%$ to $42.68 \%$ over the period 2011-2013. The year 2012 was the first year in which reporting under IFRS was mandatory. In the period 20112012, there was an increase of the market share by 2.36 percentage points, and in 2013 there was an increase of about 3 percentage points (Paunescu, 2015).

The objective of this study is to analyze the dynamics of audit market and financial reporting under International Financial Reporting Standards. In this respect, we have analyzed all the audit opinions of the companies listed on the Bucharest Stock Exchange, type of shares: Premium. Our hypothesis is that the auditor's change does not change the audit opinion and that Big 4 has a considerable meaning on the audit market in Romania. The structure of the paper includes the Literature review, the research methodology and general conclusions of the study.

\section{Literature review}

\subsection{An overview}

As some researchers show in literature (Booklay \& O'Leary, 2011), even if audit standards (ISA) and financial reporting standards (IFRS) differ substantially, they are closely related, forming a whole. In this context, the auditor's opinion will provide a higher level of concordance through financial information in the financial reporting under the IFRS adoption. To identify studies in the literature, we have 
selected the following keywords: adoption of IFRS, audit market, reporting and audit opinion. These keywords have been used in specialized journals such as: American Accounting Association, Elsevier, The International Journal of Accounting, Journal and Accounting Information Systems, Taylor and Francis. The application of IFRS leads to an understandable institutional context and it has an important impact in the enforcement system (Sucher \& Jindrichovska, 2004).

The usefulness of financial information increases the confidence of stakeholders concerning financial statements (Hayes et al., 2015). The degree of stakeholders' expectations will remain high even if there is an insignificant gap between the reality and the figures reported (Berheci, 2010). There are two substantial elements that can influence this discrepancy like: (1) the consequences of accounting frameworks could increase the quality of accounting information (Barth et al., 2008) and (2) faithful representation which is described in the financial statements represents the intervention of audit companies (Hayes et al., 2015). Through the audit report, financial auditors have the responsibility to assure the quality of financial statements, under significant aspects, under IFRS framework.

The high degree of competition and the introduction of new information technologies lead to internalization and globalization (Burns \& Baldvinsdottir, 2005). Creating the accounting profession is the result of closure for assuring the protection from different professional groups (Velayutham \& Rahman, 2000). The evolution of accountants was influenced by the globalization of economies and the frequent changes in the business environment (Elliot \& Jacobson, 2002). More, following the stereotype, accounting is "the language of the business" (Jeacle, 2008). The advent of IFRS maximized the harmonization of accounting regulations and stimulated the accountants to embed different national and international cultures (Ball et al., 2003). With the growth of globalization, convergence with IFRS has become an increasingly necessary and used option. Starting with 2005, EC Regulation no. No 1606/2002 of the European Parliament and of the Council of 19 July 2002 on the application of international accounting standards which are only applicable to listed companies in the preparation of consolidated accounts has been put into effect with a view to increasing the transparency of financial reporting. Currently, these norms are accepted in 175 countries and their number continues to grow (IASB, 2018).

Global reporting has undergone considerable changes in the last decade of time. A major change was brought by the adoption of International Financial Reporting Standards. IFRSs are the main standards issued by the IASB to develop the quality of accounting principles (Chen \& Zhang, 2010) and to standardize them globally to enhance the quality of financial reporting (Tyrrall et al., 2007), risk reduction and capital cost (Leuz \& Verrecchia, 2000), facilitates financial investment and amplifies the growth of the global economy (Street \& Bryant, 2000; Pacter, 2001; Ball, 2006; Pickard, 2007; Chen \& Zhang, 2010; Peng \& Bewley, 2013). 
Audit firms assess the accuracy of financial statements based on GAAP and accounting standards (Arens et al., 2007). Therefore, the audit increases the credibility of the companies issuing the financial statements, which can lead to capital and investment growth (Khurana \& Raman, 2004), which facilitates compliance with the financial reporting legislation in force (Li et al., 2007; Rezaee, 2009). Based on the DeGeorge (2013) study we can argue that determining the size of audit spending helps us to observe the effects of adopting IFRS as these are the most measurable cash outflows of audit firms. The disclosure of standards on financial statements varies according to country policy, which hampers investors' decisions. These International Financial Reporting Standards (IFRS) respond to the current challenge of how financial statements are made. Applying IFRS as a global standard has led to the disclosure of the details and processes of professional judgment with a high impact during the presentation of the financial statements. Widyawati and Anggraita (2013) demonstrate that adopting IFRSs are inherent difficulties because the complexity of reporting needs to be complete. Therefore, the work effort is higher because it has to assess the financial statements, and the auditors need more time to complete the audit report. This latter report requires a time extension, as publication of financial statements may be postponed (Wulandari \& Lastanti, 2015). Fair value is a source of risk that occurs with the adoption of IFRS and is present through the following standards: IAS 16 Property, IAS 40 Investment Property, IFRS 5 Non-recoverable Assets Held for Sale, IFRS 8 Operating Segments, IAS 36 Impairment of Assets, IAS 37 Provisions, Contingent Liabilities and Contingent Assets, IAS 38 Intangible Assets and IAS 39 Recognition and Measurement of Financial Instruments (Ahmed et al., 2013). For example, IFRS 3 requires enterprises to recognize and measure at fair value all the purchased assets and liabilities, including intangible assets and contingent liabilities that have not been previously recorded by the acquiree (Glaum et al., 2013)

Financial reporting includes all the accounting information that is audited and the efficiency of the financial reporting system (disclosure, engl.). In a jurisdiction or countries is an essential element for the development of efficient corporations, a transparent capital market and the overall development of the economy. However, the effectiveness of a financial reporting system depends to a large extent on a complex system of institutional factors (Ball et al, 2000). The audit report, issued at the end of the audit mission, increases the trust of the stakeholders indicating that the financial statements are in line with the reference financial reporting framework (Habib et al., 2014). In 2013, Berinde and Grosanu (2013) attest that Big 4 auditors are mostly elected by local / foreign investors as well as by seniors as they give greater credibility to audited financial statements.

As regards the adoption of IFRS, it has a considerable impact on the firm's costs (Hail et al., 2010). Regulators argue that IFRSs enhance the quality and comparability of global financial reporting suggesting that these audit costs can be 
reduced as a first result of adoption (Kim et al., 2012; De George et al., 2013). In this respect, the adoption of IFRS increases the quality of financial reporting by reducing the number of errors encountered in the financial statements, limits managerial discretion, improves the accounting decision-making process, providing better information quality in line with current legislation (Barth et al., 2008). These arguments lead voluntarily to reducing risk and audit costs (Kim et al., 2012). Undoubtedly, the adoption of IFRS may lead to an increase in audit spending, taking into account the complexity of the audit, the quality of financial reporting and the legal regime in that country.

There are a number of studies investigating the adoption of IFRS, namely: in Australia (DeGeorge et al., 2013), China (Chen \& Zhang, 2010; Peng \& Bewley, 2010), in the European Union (Kim et al., 2013). Many studies on audit spending target the United States, Australia, Canada and Hong Kong while studies on emerging markets are limited. If a country benefits from "emerging market" status, it means that both active and passive funds that use the MSCI Emerging Markets as a benchmark can invest in listed companies in that country, leading to significant growth foreign investment (Musah, 2018).

The adoption of IFRSs leads to the following changes in the audit market, namely:

- Increases expenditure on audit services;

- The change of auditor and the concentration of the audit market;

- Receive the delay in issuing the audit report;

- The cost of own capital (Daske, 2006)

On the other hand, the enigmatic truth of Mark Stevens (1991) used by Zeff (2003b: 276) showed that "Beyond the issue of size, the firms must face a serious question: What, exactly, do they want to be? For generations, the Big Eight were proud of their role as audit professionals $[\ldots]$ as the firms become more intimately involved with their clients through their consulting practices, as they think of themselves more and more as consultants who happen to do audits [...]".

In the same vein, Big 4 companies deemed that "the traditional roles of major accounting firm - participating in standard setting and developing guidance on the application of accounting standards" (Tokar, 2005: 64). Easily, we can observe that the results for the period 2016-2018 attest the reality of Big 4 to rule the figures taking into consideration that these companies rely on financial resources to increase IFRSs competences in time.

\subsection{Romanian context}

The structure of the audit market in Romania has evolved under the constant pressure of the political events, asking and offers of the audit services and economical ones. 
During communism, the accounting profession was minimized to simple bookkeeping. Therefore, the Romania accounting adjusted taking into consideration the demands of the market. After 1989, the professional bodies appeared as The Body of Expert and Licensed Accountants of Romania (1992) and Chamber of Financial Auditors in Romania (CFAR) in 1999 at the require of the World Bank and International Monetary Fund (King et al., 2001), which are nowadays IFAC (International Federation of Accountants) members. The scope of IFAC is to create standards on audit, assurance and ethics and to guide the accounting profession and being part of it implies an outward dependency like tension for continuing changes. About the relationship with foreign institutions, ICAEW (Institute of Chartered Accountants in England and Wales) and CIMA (Chartered Institute of Management Accountants) try to connect with Romania market (Albu, 2013).

The audit activity in our country is authorized by CFAR, under the total sight of the Council for the Public Oversight of Statutory Audit Activity. The principal objective and mission of (CFAR) is represented by the strong public recognition of the financial audit profession in Romania and obtaining its enhanced development by fully applying International Standards on Auditing and the Code of Ethics issued by the International Federation of Accountant. As a result, financial auditors in Romania are providing high quality services for the public interest and in the benefit of the business market and accountancy in Romania (CAFR, 2016).

In terms of market concentration, we can notice an important number of auditors and audit firms in Bucharest, which surpasses $45 \%$ of the total. This can be explained by the large number of companies with their registered office in the Romanian capital. Other important points are Brasov, Cluj, Iasi and Prahova. Thus, the companies are distributed fairly, over Romania, which are found in the main economic functions in each area.

Taking into account the evolution of Romanian accounting, this was marked by the gradual transition from the implementation of the French inspirational accounting system to the period of intensification of the internationalization process. According to OMPF no. 1938/2016, companies whose securities may be traded on a regulated market are required to present IFRS financial statements (Ionaşcu et al., 2007). Generally, accounting served as an instrument for central institutions like Central Statistical Office or Ministry of Finance) without having the possibility to make decisions in a company (Schroll, 1995) and the unique goal of financial reporting was to fulfill the accounting statements.

The Evolution of Romanian Accounting from 1989 to the present:

- The period 1990-1993 is represented by the application of the Soviet-type accounting system, during which the Accounting Law no. 82/1991. 
- The period 1994-1999 was marked by the implementation of the French inspirational accounting system. In this sense, the state played a role as a normalizer but also a main user of the financial information, which led to an asymmetry over the information demand and supply relative to other users.

- The period 1999-2006 shows a gradual shift towards the harmonization of the accounting system with the International Standards and the European Directives based on the following Ordinances: 94/2001, 306/2002, 1876/2003, $3055 / 2009$, and $1802 / 2014$. Thus, this period is marked by the harmonization of the Anglo-Saxon accounting system in line with International Financial Reporting Standards.

- The period 2006-2018 is the period of intensification of the internationalization process in which the credit institutions that precede the companies listed on BVB apply the International Financial Reporting Standards.

In Romania, the financial audit is:

- recognized all the time, as a separate partition within the accounting profession;

- an outcome of the international tendency imposed by the country's incorporation into the European Union;

- a demand of the World Bank, which is based on the growth in the credibility and attractiveness of the business environment and, thus, stimulating foreign and domestic investments (Popa et al., 2014).

Auditing reflects a mechanism of control, a tool to increase constantly the credibility of the financial picture of a company. The auditing internationalization is associated with the concept of big auding firms. The major changes in audit and accounting are performed by Big 4 companies which are considered as engines of growth and internationalization (Albu et al., 2011).

Also, Big 4 played a role in mimetic and normative isomorphism leading to an increased quality of IFRSs implementation (Albu et al., 2010). Being experts and important actors in IFRS field, Big 4 can increase the knowledge of companies regarding the national and international context (Nurunnabi, 2017). The audit companies have the opportunity to observe the organization from outside, having a transparent picture about financial statements with all the necessary details. Furthermore, there is a correlation between financial interest of Big 4 companies and the adoption of IFRS (Chand \& White, 2007).

Audit reporting is a complex activity, and the opinion approved by the auditor has an important contribution to investor decisions (Cordos \& Fulop, 2013). From the above, it can easily be noticed that the business accounting reform was externally conditional, not being the main goal, the EU accession strategy. The Romanian 
framework was changed by IFRS adoption, regarding the accounting system. For example, at our country level, the impact of these standards, the IAS / IFRS on information quality, has not been tested at all. The reform was represented only by a set of legislative changes on accounting transactions, while ignoring the other components of the infrastructure of an efficient financial reporting system (Jannis et al., 2019). Financial reporting standards are only one of the components that constitute the infrastructure of an efficient system of financial reporting (Holthausen, 2013). The benefits of financial reporting under IFRS are transparency, comparability, relevance and educational expertise (Albu et al., 2020). Furthermore, in time, accountants will have the possibility to become consultants, having a strong background of IFRS (IFAC, 2004).

Bunea (2006) found that several issues appeared to implement IFRS as: insufficient financial resources, professional judgment and big difficulties concerning accounting profession. The future accountants have to grow up the level of: (1) compliance, (2) strategic and commercial and (3) people related (ICAA, 2004). In this context, the applicable accounting framework and the affiliation to an important auditors' category have a certain influence about issuing a type of audit opinion (Grosu et al., 2015).

Another research revealed that the IFRS adoption decreased the number of unqualified opinion. About 2011, more than $81 \%$ presented unqualified opinion and in 2013, after the transition year, only 73\% registered this type of audit opinion (Paunescu, 2015). The auditors' opinions are the principle theme of IFRS studies (Abdullah \& Zhameshov, 2014; Larson \& Street, 2004; Nurunnabi, 2017), taking into account the efficacy to audit various client firms.

\section{Research methodology}

In order to observe the relationship between Big 4 / Non-Big 4 and the type of audit opinion issued by them, a non-parametric Mann-Whitney test was applied. This Mann-Whitney U test (Wilcoxon-Wilcoxon-Mann-Whitney Test) is a nonparametric test of a null hypothesis that there is a probability that a single randomly chosen value from any sample may be less higher than a value randomly selected from another sample. The Whitney test differs from the $\mathrm{T}$ test because it is not required to assume all normal distributions. This test is used to see whether two independent samples were selected from the same distribution. In addition to this test developed by Mann and Whitney, there are still other tests to formulate null and alternative assumptions, but we have chosen this test because it is best suited for the type of variables chosen.

In Romania, for the period 2016-2018, we analyzed the companies listed on the Bucharest Stock Exchange, which traded Premium shares, because they are the most important actors from market share. In this regard, we observed the audit reports to 
see the percentage of companies audited by Big 4 and the audit report. Concerning Non-Big 4 companies, it is difficult to issue a qualified opinion for a listed company, taking into account the desire of the company's management not to lose an important client and the market's rivalry. For Premium shares traded on Bucharest Stock Exchange, current results show that the type of audit opinion is not correlated with the class of the audit company, contrary to other research studies where the unqualified opinion recorded 85 percentages points for Non-Big 4 companies.

\section{Results}

Analyzing the audit reports of companies listed on the Bucharest Stock Exchange, it was possible to test the hypothesis that the change of the audit firm (from Non-Big 4 to Big 4) is directly related to the change of audit opinion. This hypothesis was not validated during the analyzed period, 2016-2018. The data was collected manually, inspecting all audit opinions for all premiums of the companies listed on the Bucharest Stock Exchange In 2018, Deloitte issued two reservations with reservations and for one company it was impossible to express a opinions and just one non-Big 4 company issued a disclaimer. In 2017, Deloitte issued two reservations for the same companies as in the previous year, and two more reserved reviews for Non-Big 4. In 2016, Deloitte issued three unqualified opinions and a single Non-Big 4 company issued an opinion with reservations.

Table 1: Audit opinion by type of auditor - year 2016

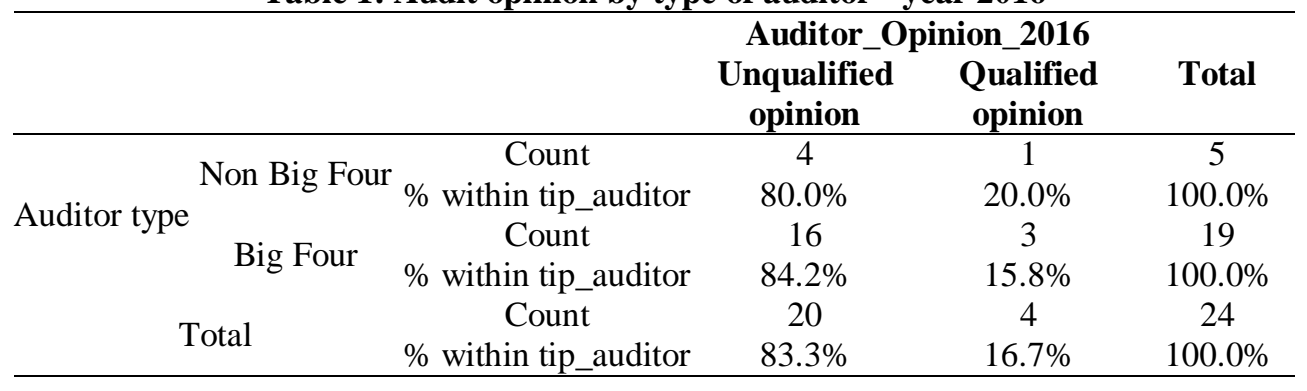

In 2016, $80 \%$ of the non-Big Four auditors had unqualified opinion, and the remaining $20 \%$ of these were in reserve for the listed companies listed on the Bucharest Stock Exchange, a type of shares: Premium. Regarding the Big Four auditors, $84.2 \%$ had unqualified opinion and $15.8 \%$ reserved.

Table 2: Audit opinion by type of auditor - year 2017

\begin{tabular}{cccccc}
\hline & & & \multicolumn{4}{c}{$\begin{array}{c}\text { Auditor_opinion_2017 } \\
\text { Unqualified } \\
\text { opinion }\end{array}$} & $\begin{array}{c}\text { Qualified } \\
\text { opinion }\end{array}$ & Total \\
\hline \multirow{2}{*}{$\begin{array}{c}\text { Auditor } \\
\text { type }\end{array}$} & \multirow{2}{*}{ Non Big Four } & Count & 3 & 2 & 5 \\
& Big Four & Count & $60.0 \%$ & $40.0 \%$ & $100.0 \%$ \\
\hline
\end{tabular}




\begin{tabular}{|c|c|c|c|c|}
\hline & & Auditor_o & ion_2017 & \\
\hline & & $\begin{array}{c}\text { Unqualified } \\
\text { opinion }\end{array}$ & $\begin{array}{c}\text { Qualified } \\
\text { opinion }\end{array}$ & Total \\
\hline & $\%$ within tip_auditor & $89.5 \%$ & $10.5 \%$ & $100.0 \%$ \\
\hline Total & Count & 20 & 4 & 24 \\
\hline lotal & $\%$ within tip_auditor & $83.3 \%$ & $16.7 \%$ & $100.0 \%$ \\
\hline
\end{tabular}

Under the IFRS adoption, the auditor's affiliation to the Big 4 and the type of the audit opinion issued by Big 4/ non-Big 4 entities, Table 2 emphasizes the percentage for each sort. In 2017, 60\% of the Non Big Four auditors had unqualified opinion, and the remaining $40 \%$ of them with a reservation for the listed companies listed on the Bucharest Stock Exchange, type of shares: Premium. Regarding the Big Four auditors $89.5 \%$ had unqualified opinion and $10.5 \%$ had reservations.

Table 3: Audit opinion by type of auditor - year 2018

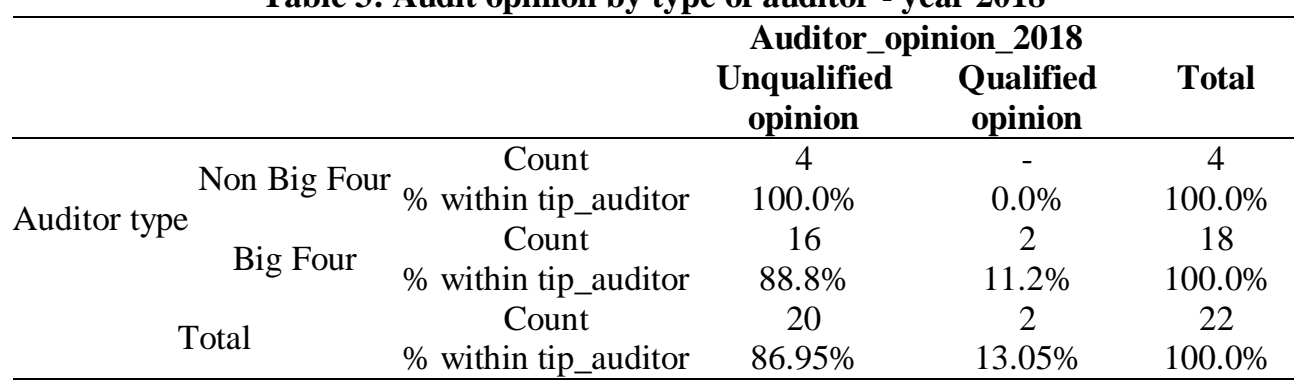

In 2018, 100\% of the Non Big Four auditors had unqualified opinion, for the listed companies listed on the Bucharest Stock Exchange, type of shares: Premium. Regarding the Big Four auditors, 86.95\% had unqualified opinion and 13.05\% qualified opinion. Furthermore, using the Hi-Square Test, it was verified whether there is a statistically significant association between the type of auditor and the audit opinion. The threshold of significance is $5 \%$.

The information displayed in Table 3 outlines another survey having the same topic and results, for another period of time. For the period 2008-2012, Cordos and Fulop (2013) concluded that the majority of companies on Romania market are audited by Big firms and the trend seemed to continue from a year to another one.

The same association was analyzed by Eshleman and Guo (2014) and the results attested a positive relationship between the auditor's type and the quality of the audit engagement, which leads to a high degree of credibility about audited financial statements. Jaba et al. (2015) argued the same outcome for Romania listed companies, depending on a certain type of auditor. 
Table 4: The Mann-Whitney test for verifying the association between the type of auditor and the audit opinion in 2016

\begin{tabular}{cc}
\hline & Audit_opinion 2016 \\
\hline Mann-Whitney U & 45.500 \\
Wilcoxon W & 235.500 \\
Z & -0.220 \\
Asymp. Sig. (2-tailed) & 0.826 \\
Exact Sig. [2*(1-tailed Sig.)] & $0.891^{\mathrm{b}}$ \\
a. Grouping Variable: Tip_auditor \\
b. Not corrected for ties. \\
\hline
\end{tabular}

According to Table 4, the asymptotic significance associated with Mann-Whitney's statistics is 0.826 higher than 0.05 , meaning that there are no significant statistical differences between the auditor's type in the audit opinion in 2016, at a significance level of $5 \%$.

Table 5: The Mann-Whitney test for verifying the association between the type of auditor and the audit opinion in 2017.

\begin{tabular}{cc}
\hline & Audit_opinion_2017 \\
\hline Mann-Whitney U & 33.500 \\
Wilcoxon W & 223.500 \\
Z & -1.540 \\
Asymp. Sig. (2-tailed) & 0.123 \\
Exact Sig. [2*(1-tailed Sig.)] & $0.331^{\mathrm{b}}$ \\
a. Grouping Variable: tip_auditor \\
b. Not corrected for ties. \\
\hline
\end{tabular}

According to Table 5, the asymptotic significance associated with the MannWhitney test statistic is 0.123 , higher than 0.05 , which implies that there are no statistically significant differences between the auditor's type in the audit opinion in 2017 , at $5 \%$ level of significance.

Table 6: The Mann-Whitney test for verifying the association between the type of auditor and the audit opinion in 2018

\begin{tabular}{cc}
\hline \multicolumn{2}{c}{ the type of auditor and the audit opinion in 2018 } \\
\hline Mann-Whitney U & Audit_opinion 2018 \\
Wilcoxon W & 45.500 \\
Z & 235.500 \\
Asymp. Sig. (2-tailed) & -.220 \\
Exact Sig. [2*(1-tailed Sig.)] & .826 \\
a. Grouping Variable: tip_auditor \\
b. Not corrected for ties. \\
\hline
\end{tabular}


According to Table 6, the asymptotic significance associated with the MannWhitney test statistic is 0.826 , value that is higher than 0.05 , implying that there are no statistically significant differences between the auditor's type in the audit opinion in 2018 at a materiality level 5\%. In this study, it was analyzed whether companies changed their auditors had changes in the audit opinion during the period 2016-2018. Moreover, the change of the company that audited existed, but not to accede to a superior audit firm. Therefore, there was a change in the Big 4 auditing company that led to another audit opinion. Regarding Non-Big 4, there was a change in the audit firm that did not lead to another audit opinion.

On the other hand, another research by Grosu et al. (2015) attests that the affiliation to a certain auditor from Big 4 increases the quality of financial statements and after the IFRS adoption increases the number of qualified opinions.

Table 7: The distribution of Big 4 companies for Premium Shares traded on Bucharest Stock Exchange, the period 2016-2018

\begin{tabular}{lrrrrrr}
\hline \multirow{2}{*}{ Auditor } & \multicolumn{2}{c}{$\mathbf{2 0 1 6}$} & \multicolumn{2}{c}{$\mathbf{2 0 1 7}$} & \multicolumn{2}{c}{2018} \\
& Number & Percentage & Number & Percentage & Number & Percentage \\
\hline Deloitte & 11 & $55 \%$ & 9 & $45 \%$ & 10 & $50 \%$ \\
KPMG & 2 & $10 \%$ & 2 & $10 \%$ & 2 & $10 \%$ \\
PWC & 2 & $10 \%$ & 3 & $15 \%$ & 3 & $15 \%$ \\
EY & 4 & $20 \%$ & 5 & $25 \%$ & 4 & $20 \%$ \\
NonBig4 & 1 & $5 \%$ & 1 & $5 \%$ & 1 & $5 \%$ \\
Total & 20 & $100 \%$ & 20 & $100 \%$ & 20 & $100 \%$ \\
\hline
\end{tabular}

From the data in Table 7, we ca notice that for BSE listed companies which trade Premium shares, only one entity is audited by non-Big 4 and the rest of the entities of the sample is audited by Big 4, for the entire period. In the same time, we analyzed for the period 2016-2018 the top of Big 4 companies. Delloite for the entire period picks up the top and KPMG audited only two companies.

We can observe that Big 4 leads the market audit, in the period 2016-2018 and the qualified opinion is the most frequently, even if they have the highest demand for auditing. Francis (2004) emphasized that the quality of audit is superior for Big 4 companies, which can be confirmed by the highest percentage of 84 points. Another study by Daniels and Booker (2010) confirms our results about the association between the rotations of a firm and the change of the audit opinion. More, they show that the rotation of external auditors don't affect the quality of audit service.

Even if the interpretation of Big 4 is the same (Gray \& Ratzinger, 2010), the majority of stakeholders prefers them than small audit companies, taking into consideration 
the IFRS resources which lead them to an important expertise. The graph emphasizes that most of companies prefers Big 4 and the percentage for companies audited by non-Big 4 is 5 points for the entire analyzed period, even though the fees are higher.

\section{Conclusions}

Audit reporting represents a complex activity and the opinion issued by audit companies constitutes a big contribution regarding the investors' decisions. IFRS transition is justified by the growth of the quality of financial statements as transparence, reliability and comparability. In these circumstances, the quality of financial information reported will affect the audit opinion issued by Big 4/ non-Big 4 companies.

The main objective of this study is to analyze the structure of the financial audit market for companies listed on the Bucharest Stock Exchange, focusing primarily on Premium shares. Between the years 2016-2018, the results show that $81.81 \%$ of companies are audited by Big 4 , while about $18.19 \%$ are audited by Non-Big 4 . A lower percentage of market concentration can be observed by comparing the other countries from the European Union (Soedaryono, 2015). Analyzing the audit reports of companies listed on the Bucharest Stock Exchange, it was possible to test the hypothesis that the change of the audit firm (from Non-Big 4 to Big 4) is directly related to the change of audit opinion.

The total number of clients audited by Big 4 increased with $89.96 \%$ in the analyzed period. At the same time, it could be seen that out of a total sample of 20 companies, a single Big 4 changed its audit opinion. In this sense, if the old company that audited was Big 4, the next one will be in the same class and will not be a non-Big 4 company. In our case, in 2017, EY issued an unqualified audit opinion, although in the previous year, Deloitte issued a qualified opinion. More, a change of the audit firm is not directly associated to the change of audit opinion. The quality of the audit is represented by the ability of the audit firm to find and report errors at the customer's level, to make decisions by providing expertise on the client's information system and finally to provide an opinion conveyed in the audit report (DeAngelo, 1981).

We can conclude that in emerging economies, the number of companies audited by Big 4 is less than in our country (Paunescu, 2005) and there is a positive association between the type of audit opinion and the rotation of the audit firm. Regarding Romanian market the results of the study show signs of maturation and a good functioning in line with the known of capital markets and continuous improvement of audit market. 


\section{References}

Abdullah, A., Khadaroo, I., \& Zhameshov, N. (2014) "The relevance of International Financial Reporting Standards to Kazakhtan: Perception of auditors", International Journal of Accounting and Finance, vol. 4, no.3: 305-322

Albu, C.N., Albu N., Szilveszter, F.P.P., \& Vladu, D.C. (2011) "The power and the glory of Big 4: a research note on independence and competence in the context of IFRS implementation", Accounting and Management Information Systems, vol. 10, no. 1: 43-54

Albu, N. (2013) "Exploring the recent evolution of the accounting profession in Romania - an institutional approach", Accounting and Management Information Systems, vol. 12, no. 4: 537-552

Albu, N., Albu, C.N., \& Gray, S.J. (2020), "Institutional factors and impact of international financial reporting standards: the Central and Eastern Europe experience", Accounting Forum, in press

Albu, N., Albu, C.N., Bunea, S., Calu D., \& Girbina, M.M. (2010) “A story about IAS/IFRS implementation in Romania - an institutional and structuration theory perspective", Journal of Accounting in Emerging Economies, vol. 1, no. 1: 76-100

Arens, A., Elder, R., Beasley, M., \& Splettstoesser-Hogeterp, I. (2007) Auditing and Other Assurance Services (10 ${ }^{\text {th }}$ Edition), Toronto: McGraw-Hill

Ball, R. (2006) "International Financial Reporting Standards (IFRS): pros and cons for investors", Accounting and Business Research, vol. 36, no.1: 5-27

Ball, R., \& Kothari, S. P. (2000) "The effect of international institutional factors on properties of accounting earnings", Journal of Accounting and Economics, vol. 29, no 1: 1-51

Ball, R., Robin A., \& Wu, J. (2003) "Incentives versus standards: properties of accounting income in four East Asian countries", Journal of Accounting and Economics, vol. 36, no.1: 235-270

Barth, M., Landsman, W., \& Lang, M. (2008) "International Accounting Standards and accounting quality", Journal of Accounting Research, vol. 46, no. 3: 467-498

Beattie, V., \& Fearnley, S. (1994) "The changing structure of the market for audit services in the UK - A descriptive study", The British Accounting Review, vol. 26, no. 4: 301-322

Berheci, M. (2010) Valorificarea raportarilor finaciare. Sinteze contabile: teorie, analize, studii de caz [The use of financial reporting. Accounting synthesis: theory, analyses, case studies], Bucharest: Ed. CECCAR

Berinde, S. \& Grosanu, R. (2013) "Particularities concerning the beneficiaries of audit services provided by Big 4 companies: Evidence from Romania", Annales Universitatis Apulensis Series Economica, vol 15, no 2: 483-492 
Booklay, P. \& O’Leary, C. (2011) "Determining The Strength of Auditing Standards and Reporting", Australasian Accounting, Business and Finance Journal, vol. 7, no 4: 18-26

Bunea, S. (2006) "Analysis of the impact of the convergence process on the evolution of national accounting systems and lessons for Romania", The $\mathrm{XVI}^{\text {th }}$ Congress of Romanian Accounting Profession Bucharest, 15-16 September

Burns, J. \& Baldvinsdottir G. (2005) “An institutional perspective of accountants' new roles-the interplay of contradictions and praxis", European Accounting Review, vol. 14, no.4: 725-757

Chand, P. \& White M. (2007) "A critique of the influence of the influence of globalization and convergence of accounting standards in Fiji", Critical Perspectives on Accounting, vol. 18: 605-622

Chen, J. \& Zhang, H. (2010) "The impact of regulatory enforcement and audit upon IFRS compliance- evidence from China”, European Accounting Review, vol. 19, no. 4: 665-692

Choi, S., Choi, Y., \& Kim, B. (2018) "Auditors' strategic audit pricing: evidence from the pre- and post-IFRS Periods", Journal of Practice and Theory, vol. 37, no. 4: 75-94

Cordos, G.S. \& Fulop, M.T. (2013) "Considerations related to listd entities preference to be audited by large audit firms", Audit Financiar, vol. 11, no. 10: 17-23

Daniels, B. \& Booker, Q. (2010) "The effects of audit firm rotation on perceived external auditor independence and audit quality", Research in Accounting Regulation, vol. 23, no. 1: 78-82

Daske, H. \& Gebhardt, G. (2008) "International financial reporting standards and experts' perceptions of disclosure quality", Abacus, vol. 42, no. 3: 2-12

DeAngelo, L.E. (1981) "Auditor size and audit quality", Journal of Accounting and Economics, vol. 3, no. 3: 183-199

Dihn, N. \& Poit, C. (2014) "IFRS adoption in Europe and audit market concentration", working paper

Elliot, R.K. \& Jacobson, P.D. (2002) "The evolution of the knowledge professional", Accounting Horizons, vol. 16, no.1: 69-81

Eshleman, J.D \& Guo, P. (2014) "Do Big 4 auditors provide higher audit quality after controlling for the endogenous choise of auditor?", Auditing: A Journal of Practice \& Theory, vol. 33: 197-219

Francis, J. R. \& Simon, D.T. (1987) „A test of audit pricing in the small client segment of the U.S. audit market", The Accounting Review, vol. 62: 48-65

Francis, J.R. (2004) "What do we know about audit quality?", British Accounting Review, vol. 36, no. 4: 345-368

Fung, S., Gul, F.A. Raman, K., \& Zhu K. (2009) “Audit market concentration, auditor's reputation as global and country level market leader, and investor perceived audit quality", working paper 
Gray, G. \& Ratzinger, N. (2010) "Perceptions of preparers, users and auditors regarding financial statement audits conducted by Big 4 accounting firms", International Journal of Disclosure and Governance, vol. 7, no. 4:344-363

Grosu, M., Robu I.B., \& Istrate, C. (2015), "Exploratory Study Regarding The Impact of IFRS on the Audit Opinion in the Case of Romanian Listed Companies", Audit Financiar, vol. 13, no. 7: 81-93

Haapamäki, E. (2018) "How has IFRS impacted financial reporting for unlisted entities?", Accounting and Management Information Systems, vol. 17, no. 1: $5-30$

Habib, A., Jiang, H., Bhuiyan, U., \& Islam, A. (2014) "Litigation risk, financial reporting and auditing: A survey of the literature", Research in Accounting Regulation, vol. 26, no. 2: 145-163

Hay, D., \& Jeter, D. (2011) „The pricing of industry specialization by auditors in New Zeeland", Accounting and Business Research, vol. 2, no. 2: 171-195

Hayes, R., Dassen, R., Schilder A., \& Wallage, P. (2005) Principles of Auditing. An introduction to International Standards of Auditing, $2^{\text {th }}$ edition, Pearson Education Ed

Holthausen, R. W. (2013) “Testing the relative power of accounting standards versus incentives and other institutional features of influence the outcome of financial reporting in an international settings", Journal of Accounting and Economics, vol. 36: 271-283

IASB (2018) Conceptual Framework for the Preparation and Presentation of Financial Statements, Chapter 3: Financial statements and the reporting entity, Perspective adopted in financial statements and going concern assumption: $14-26$

ICAA (2004) "The CFO of the future - leading through influence and integrity", Institute of Chartered Accountants in Australia, available at: http://icaa.org.au

Ionașcu, I., Ionașcu, M., Olimid, L., \& Calu, D. (2007) “An empirical evaluation of the costs of harmonising romanian and accounting international regulations (EU Directives and IAS/IFRS)", Accounting in Europe, vol. 4, no. 2: 169206

Istrate, C. (2018) "Financial auditing and financial reporting for Romanian stateowned companies - modified opinions and observations", Accounting and Management Information Systems, vol. 17, no. 4: 513-531

Jaba, E., Robu, I.B., \& Balan, C.B. (2015) "Statistical evidence on the selection decision of financial auditors, in the case of Romanian listed companies", Audit Financiar, vol. 13, no. 4: 3-15

Jannis, B., Holger, D., Ferdinand, E., \& Luzi, H. (2019) "A tale of two regulators: risk disclosures, liquidity and enforcement in the banking sector", working paper

Jeacle, I. (2008) "Beyond the boring grey: The construction of the colorful accountant", Critical Perspectives on Accounting, vol. 19: 1296-1320 
Khurana, I. \& Raman, K. (2004) "Litigation risk and the financial reporting credibility of big 4 versus non-big 4 audits: evidence from Anglo-American countries", The Accounting Review, vol. 79, no. 2: 578-591

King, N., Beattie, A., Cristescu, M.M., \& Weetman, P. (2001) "Developing accounting and audit in a transition economy: the Romanian experience", European Accounting Review, vol. 10, no.1: 149-171

Klarskov, J.P. (1998) "Reinventing auditing, redefining consulting and independence", European Accounting Review, vol.7, no.3: 517-539

Laptes, R., Popa, A.F., \& Dobre, F. (2014) "Research on the evolution of Financial Audit in Romania- Past, Current and Future Trends", Proceedings Economics and Finance, vol. 15: 807-814

Larson, R., \& Street, D. (2004) "Convergence with IFRS in an expanding Europe: Progress and obstacles identified by large accounting firms' survey", Journal of International Accounting, Auditing and Taxation, vol.13, no. 2: 89-119

Leuz, C. \& Verrecchia, R. (2000) "The economic consequences of increased disclosure", Journal of Accounting Research, vol. 38: 91-124

Li, Y., Roge, J., Rydl, L. \& Hughes, J. (2007) "Achieving Sarbanes- Oxley compliance with XBRL- based ERP ad continuous auditing", Issues in Information Systems, vol. 18, no. 2: 44-59

McInnis, J. \&Mergenthaler, D. (2012) "Rules-Based Accounting Standards and Litigation", American Accounting Association, vol.87, no. 4: 1247-1279

Musah, A. (2018) „The effects of IFRS adoption and Big 4 audit firms on audit and non-audit fees: Evidence from Ghana The effect of IFRS adoption and Big 4 audit firms on audit and non-audit fees: Evidence from Ghana", Accounting and Management Information Systems, vol 17, no. 3: 330-352

Nobes, C., \& Parker, R. (2008) Comparative international accounting, Prentice Hall

Nurunnabi, M. (2017) “Auditor's perceptions of the implementation of International Financial Reporting Standards (IFRS) in a developing country", Journal of Accounting in Emerging Economies, vol.7, no. 1: 108-133

Pacter, P. (2001) "What exactly is convergence?", International Journal of Accounting, Auditing and Performance Evaluation, vol. 2, no. 2: 67-83

Paunescu, M. (2015) "The Romanian audit market structure in case of listed companies and the impact of adopting IFRS", Procedia Economics and Finance, vol. 32: 686-693

Peng, S. \& Bewly, K. (2010) "Adaptability to fair value accounting in an emerging economy: a case study of China's IFRS convergence", Accounting, Auditing \& Accountability Journal, vol.23, no.8: 982-1011

Pickard, G. (2007) "Simplifying global accounting”, Journal of Accountancy, vol. 204, no. 36-39

Pong, C. (2003) "Auditor concentration: a replication and extension for the UK audit market 1991-1995", Journal of Business, Finance\& Accounting, vol. 26, no. 3: $451-475$ 
Reckers, P.M.J., Jennings, M., Lowe, D.J., \& Pany, K. (2007) “Judges' attitudes toward the public accounting profession", European Accounting Review, vol.16, no.3: 625-645

Richard, C. (2006) "Why an auditor can't be competent and independent: A French case study", European Accounting Review, vol. 15, no. 2: 153-179

Schroll, R. (19995) "The new accounting system in the Czech Republic", European Accounting Review, vol. 4, no.4: 827-832

Soedaryono, B. (2017) „Relationship between abnormal audit fees and audit quality before and after the adoption of IFRS in automotive and transportation are listed in Indonesia Stock Exchange", vol. 6: 16-25

Street, D. \&Bryant, S. (2000 "Disclosure level and compliance with IASs: a comparison of companies with and without IS listing and filings", The International Journal of Accounting, vol.35, no.3: 305- 329

Sucher, P. \& Jindrichovska, I. (2004) "Implementing IFRS: A case study of Czech Republic", Accounting of Europe, vol 1: 109-141

Tokar, M. (2005) "Convergence and the implementation of a single set of global standards: the real-life challenge", Accounting in Europe, vol. 2, no. 1: 47-68

Tyrall, D., Woodward, D., \& Rakhimbegova, A. (2007) "The relevance of international financial reporting standards to a developing country: Evidence from Kazakhstan", The International Journal of Accounting, vol. 42, no. 1: $82-110$

Velayutham, S. \& Rahman, A. (2000) "Towards market differentiation in the accounting profession: The case of Australia and New Zeeland", Critical Perspectives on Accounting, vol. 11: 691-711

http://www.bvb.ro/

https://en.wikipedia.org/wiki/Mann\%E2\%80\%93Whitney_U_test

http://www.romanian-accountants.com/chamber-of-financial-auditors-in-romania 